\title{
Stenciling Printing Techniques for Interior Decoration in Okigwe Local Government Area
}

\author{
Alozie E.N \\ Department of Home Science / Hospitality Management and Tourism \\ Michael Okpara University of Agriculture, Umudike, Abia State, Nigeria
}

\begin{abstract}
This study examined the potentials of stenciling techniques and products for interior decoration of families in Okigwe Local Government Area of Nigeria. The Specific objective of the study was to produce design on local fabrics using stenciling techniques, examine the various ways of utilizing stenciling techniques products for interior decoration in the home, ascertain the constraints on the use of stenciling techniques products for interior decoration in the home and to ascertain the possible benefits associated with the use of stenciling techniques products. A survey research design was used for the study. The population of the study comprised of 2049 families in Okigwe Local Government Area Imo State out of which 335 families were randomly selected. A validated structured questionnaire was used to collect data for the study. Frequency and percentage were used for analysis. The findings of the study revealed to a high extent, the items from stenciling techniques products are suitable for interior decoration. The study further revealed that there is significant difference in the suitability of the products for household. Based on the findings, it is recommended that conferences, seminars and workshops should be periodically organized on stenciling techniques for families in Okigwe Local Government Area of Imo State.
\end{abstract}

Keywords: Stenciling printing techniques, interior decoration, Okigwe Local Government Area.

DOI: $10.7176 / \mathrm{JTHS} / 41-03$

Publication date:May $31^{\text {st }} 2019$

\section{INTRODUCTION}

Stenciling is a way of creating pictures or text on surfaces using a stencil. It can be used for countless times. The first element of comfort, convenience and attempt for beatification were introduced into dwelling (Ford, 2013). Thus, there is usually the desire to make the aesthetic pleasures, decorated with items that are beautiful as well as entertaining. Interior decoration is the dual art of planning and producing interior of structures on a basic function, comfort, convenience and esthetic appeal (Ford. 2016). The professional interior designer through training and experience plans design and decorates materials which are used for the furnishing of interior, homes, houses, commercial institutional structures, hotels, clubs, theaters, restaurants and other public places (Alan, 2013). Interior decoration is a multifaceted profession that includes conceptual development, communicating with the stakeholders of a project, the management and execution of the design techniques on fabric. The items used ignites beauty and excitement in the interiors of the home (Cullen, 2015). Dyes offer beauty and chance for self-expression (Griffin. 2012).

In the modern society, interior decoration of the home goes beyond decorating only with our commonly used flowers and ornamentals in the sitting room, but involves the entire rooms such as living room, kitchen, bathroom, toilet and bedrooms using different types of decorative material. In planning and designing for interior decoration in the home one must basically consider the content of quality design for the person and purpose of decoration (Ford, 2010). The decoration of the interior of home provides a revealing portrait of its inhabitant (Alan, 2013).

Dyes are substances that are used in applying color to yarn or fabric. Dyes are in the form of powders or liquid, some can be dissolved in hot water while others dissolves in cold water. Dye is a soluble coloured substance that has an affinity for a fiber or to the surface (in contrast, a pigment, is insoluble and usually has no affinity). Dye can be made from plants, animals and mineral substances (Anyakoha and Eluwa, 2010). Also, pattering of tie-dye fabric was done in so many ways namely, sewing, tying, knotting, folding, pleating, intention with stone sticks, threads with needle tighten to prevent the penetration of dye (Alan, 2013).

Tie-dye is a recent method of pattering fabric that is achieved by preventing dye liquor from penetrating all parts of the fabric (Oguntona, 2014). Tie-dye dye gained popularity in Nigeria during the great depression, when it was considered an economical way to add new color to old material pamphlet. Old cotton flour, coffee and sugar sacks were used to create new clothing and home decoration (Moris, 2009). According to Ford (2013), some simple manual techniques for designing fabric in the recent past have been popular among Nigerians in producing such textiles that reflected their culture, creativity, psychological disposition as well as aesthetic orientation. Such techniques include batiking and stenciling techniques. These products were not popular among Nigerians for use in interior decoration of homes and offices. The reason may probably be that the potentials of the product for interior decoration of the homes are not known to the people. Consequently, imported foreign 
materials are preferred to these local products as resource to interior decoration for the homes. Large quantities of these foreign materials are purchased each year for decoration of the homes and offices.

Cullen (1999) observed that in the modern societies, interior decoration of the house goes beyond decorating and designing only one room, but it involves the entire rooms such as living rooms and kitchen, bathroom, toilet and bedroom. The interior decoration of the bedroom should express intimacy, peace and quietness (Ford, 2013).

Jessy (2013) stated that interior decoration of homes should provide a revealing portrait in its inhabitants because homes are often perceived as an enclosure of comfort where objects of interests and satisfaction are displayed to make for relaxation and enjoyment. Thus, there is usually the desire to make the interior of home become a source of aesthetic pleasures, decorated with items that are beautiful as well as entertaining. The interior decoration of homes may be considered as suitable opportunity for demonstration of the skills and potentials of various textile craft. Often times the product of various designing techniques on fabrics are mostly the items used to ignite beauty and excitement in the interiors of the homes (Magnani and Rivista, 2000).

The interior decoration is a profession in which creative and technical solutions are applied within a structure to achieve a built interior environment and home lifestyle enhancement. The interior design process follows a systematic and coordinated methodology, including the study, analysis, and integration of knowledge into the creative process, whereby the needs and resources of the client are satisfied to produce an interior space that fulfils the project goals. Planning and designing for interior decoration must basically consider the suitability of the design for the person and purpose of the decoration. It is necessary to ascertain if the stenciling techniques products could add the desired beauty and excitement when used for interior decoration of the homes. This study therefore attempts to sensitize Nigerians on the importance of harnessing untapped potentials of local products in cloth making and interior decoration. Stenciling techniques and tie-dye product was of great consideration in this study.

\section{Materials and Methods}

This research work was performed in the clothing and textiles laboratory of Home Economics Department of Michael Okpara University of Agriculture Umudike, Nigeria. They include the stencil printing techniques process as well as the sewing of their respective products into household items.

\section{The Stencil Printing Techniques}

Although there are several printing techniques but the stencil printing techniques was used in this work. It involves printing design from a carved cardboard paper on the fabric to obtain repeated patterns on the surface of the fabric.

\section{Preparation of the Stencil Techniques}

In preparing the stencils, a design was drawn on a cardboard paper, laminated with a transparent cello-tape after which the laminated item was carved out and it has the shape of the design.

\section{Materials for Stencil Printing Techniques}

Printing ink, cardboard paper, foam, fabric, Pencil, Razor blade, Cellotape, printing table, blanket or thick cloth, pin, designed paper.

\section{Stencil Printing Procedure}

The intended design was drawn on a plain cardboard paper and carried out using razor blade. The printing table was covered with blanket and the carved cardboard paper was placed on the fabric. Using foarm, the mixed printing mix was carefully applied on the fabric depending on the design and pattern arrangement. Printing was done in alternate order to maintain uniformity. The material was allowed to dry and finally ironed and packaged.

\section{Research Design}

The study was a cross-sectional study involving the use of questionnaires to collect data from respondents.

\section{Area of the Study}

The geographical location of this research work is Okigwe Local Government Area of Imo State. Okigwe is the third largest city, after Owerri and Orlu, in Imo state of Nigeria. The city lies between the Port Harcourt-EnuguMaiduguri rail line. Thus, the city has grown into a major cattle transit town for the southeast and south subregions of Nigeria. Okigwe has a population of 132,237 (2005 census). Most of the inhabitants are immigrant workers from other states. Okigwe city was the primary host site of the old Imo State University (now Abia State University). Okigwe has various tourist and historical sites. The Federal Government College in the city has remained one of the best unity schools in Nigeria. Okigwe remains one of the food baskets of Nigeria with 
terrace cultivation practiced on its hilly farmlands.

\section{Population of the Study}

The study population comprised of 2049 families in Okigwe Local Government Area of Imo State.

\section{Determination of Sample Size}

The sample size for the study was 335 families of Okigwe Local Government Area. This was arrived at through a scientific method where YaroYamen's formula was adopted. This is mathematically represented thus;

$\mathrm{n}=\frac{\mathrm{N}}{1+\mathrm{N}(\mathrm{e})^{2}}$

Where $\mathrm{n}=$ sample population

$1=$ constant

$\mathrm{N}=$ population $=2049$

$\mathrm{e}=$ degree of error 0.05

By substitution and computation, this implies;

$$
\begin{aligned}
& \frac{2049}{1+2049(0.0025)} \\
& =334.69 \\
& \cong 335
\end{aligned}
$$

\section{Sample and Sampling Techniques}

This research work adopted a simple random sampling techniques to select the respondents from Okigwe Local Government Area in Imo State.

\section{Instrument for Data Collection}

Structured questionnaire was used for data collection. The questionnaire was categorized in four (4) sections; A. B, C, D.

Section A: Biodata of Respondents.

Section B: Section B comprise of the following parts;

Part. A: various ways of utilizing stenciling techniques products for interior decoration.

Part B: possible benefits associated with the use of stenciling techniques products.

Part C: suitability of the items from manual products for interior decoration.

Part D: constraints on the use of stenciling techniques products for interior decoration in the home.

A four point rating scale was used for rating. Thus, Strongly Agreed (SA), Agreed (A), Strongly Disagreed (SD), Disagreed (D) with values. 4, 3, 2, and 1 assigned respectively.

\section{Validation of Instrument}

The Instrument was validated by two experts (Lecturers) from Home Economics Department, Michael Okpara University of Agriculture, Umudike. The contribution of validates reflected in the final draft of the instrument.

\section{Reliability of the Instrument}

Reliability is how genuine, guaranteed, and reliable the instrument used is, for the purpose of the research work. In the period, ten (10) copies of the questionnaire was sampled to ten (10) colleagues, this was used as sample collection. Thus, the questionnaire was judged reliable for data collection.

\section{Data Analysis Techniques}

The statistical tools used for data analysis were frequency, mean and simple percentages (\%). Frequency was used to organize the data collected. Percentage (\%) was used to organize the demographic data of the students while mean was used to analyze the responses to research question. The mean was calculated by assigning nominal values to the response categories.

Strongly agree (SA); Agree (A); strongly disagree (SD); Disagree (D) with values 4, 3, 2 and 1 assigned respectively.

Strongly Agree 4

Agree 3

Strongly Disagree 2 
Disagree 1

Hence, the mean was computed as follow;

$\sum=\frac{\sum \mathrm{x}}{\mathrm{n}}$

To this extent, the cut-off becomes 2.5 . Any value below 2.5 is regarded as disagree while above 2.5 will be regarded as agreed.

\section{RESULTS AND FINDINGS}

Table 1: Socio-Demographic Characteristics of the Respondents

\begin{tabular}{lcc}
\hline Gender & Frequency & Percentage \\
\hline Male & 174 & \\
Female & 161 & 51.9 \\
Total & $\mathbf{3 3 5}$ & 48.1 \\
Age & & $\mathbf{1 0 0 . 0}$ \\
$31-35$ & 153 & \\
$36-40$ & 86 & 45.7 \\
40 and above & 96 & 25.7 \\
Total & $\mathbf{3 3 5}$ & 28.7 \\
& & $\mathbf{1 0 0 . 0}$ \\
Occupation & & \\
Trader & 129 & \\
Civil Servant & 121 & 38.5 \\
Farmer & 85 & 36.1 \\
Total & $\mathbf{3 3 5}$ & 25.4 \\
Academic Qualification & & $\mathbf{1 0 0 . 0}$ \\
FSLC & 98 & \\
WASC/GCE & 62 & 29.3 \\
OND & 59 & 18.5 \\
B.Sc/HND & 92 & 17.6 \\
Master's Degree & 24 & 27.5 \\
Total & $\mathbf{3 3 5}$ & 7.2 \\
\hline Source Fidd Survey & $\mathbf{1 0 0 . 0}$ \\
\hline
\end{tabular}

Source: Field Survey (2017)

From table 1 above, $51.9 \%$ comprising of 174 respondents were male while $48.1 \%$ comprising of 161 respondents were female. This implies that the majority of the respondents were male while the minority of the respondents were female.

$45.7 \%$ comprising of 153 of the respondents were within the age range of $31-35$ years. $25.7 \%$ comprising of 86 respondents were within the age range of $36-40$ years, $28.7 \%$ comprising 96 are within the age range of 40years and above. Based on the findings of this study, it is evident that the majority were within the age range of 31-35 years.

$38.5 \%$ of the respondents comprising of 129 respondents were traders. $36.1 \%$ comprising 121 respondents were civil servants. $25.4 \%$ comprising 85 respondents were farmers. This study revealed that the respondents were of different careers. The majority of the respondents were traders while the minority were farmers.

The academic qualification of the respondents were analyzed above (Table 1). $29.3 \%$ comprising of $98 \%$ of the respondents had FSLC certificate, $18.5 \%$ comprising 62 respondents had WAEC/GCE, 17.6\% comprising 59 respondents had OND certificate, $27.5 \%$ comprising 92 respondents had B.Sc/HND certificate. $7.2 \%$ comprising 24 respondents had Master's degree certificate. The study revealed that the respondents were of different academic qualification. The study suggests that the majority of the respondents had FSLC while the minority of the respondents had Msc degree certificate. 
Table 2: The various ways of utilizing stenciling techniques products for interior decoration in the home

\begin{tabular}{|c|l|c|c|c|c|c|c|c|}
\hline S/N & $\begin{array}{l}\text { What are the various ways of utilizing stenciling } \\
\text { techniques products for interior decoration in the } \\
\text { home? }\end{array}$ & $\mathbf{A}$ & $\mathbf{S D}$ & $\mathbf{D}$ & $\mathbf{X}$ & Sd & Remark \\
\hline 1 & Pillow case & 177 & 61 & 38 & 59 & 3.06 & 1.16 & Accept \\
\hline 2 & Curtain & 189 & 53 & 36 & 57 & 3.11 & 1.16 & Accept \\
\hline 3 & Table cloth & 172 & 78 & 44 & 41 & 3.13 & 1.05 & Accept \\
\hline 4 & Wall design & 209 & 59 & 32 & 35 & 3.31 & 1.02 & Accept \\
\hline 5 & Headrest & 231 & 5 & 52 & 47 & 3.25 & 1.16 & Accept \\
\hline 6 & Cushion Cover & 223 & 28 & 60 & 24 & 3.34 & 1.00 & Accept \\
\hline 7 & Armrest & 225 & 39 & 35 & 36 & 3.35 & 1.04 & Accept \\
\hline 8 & Draperies & 228 & 28 & 37 & 42 & 3.31 & 1.09 & Accept \\
\hline
\end{tabular}

Source: Field Survey (2017)

Key

$\begin{array}{lll}\mathrm{X} & = & \text { Mean } \\ \mathrm{Sd} & = & \text { Standard Deviation }\end{array}$

Various ways of utilizing stenciling techniques products for interior decoration in the home was examined in table 2 above. Out of the eight items on the various ways of utilizing stenciling techniques products for interior decoration in the home, all were accepted with mean score range of 3.06-3.35. Respondents with mean score of 3.06 agreed that pillow case is one of the various ways of utilizing stenciling techniques products for interior decoration in the home, respondents with mean score of 3.11 claimed that curtain is one of the various ways of utilizing stenciling techniques products for interior decoration in the home; respondents with mean score of 3.13 accepted that table cloth is one of the various ways of utilizing stenciling techniques products for interior decoration in the home, respondents with mean score of 3.25 attested that headrest is one of the various ways of utilizing stenciling techniques products for interior decoration in the home, respondent with mean score of 3.34 agreed that cushion cover is one of the various ways of utilizing stenciling techniques products for interior decoration in the home, respondents with mean score of 3.35 agreed that armrest is one of the various ways of utilizing stenciling techniques products for interior decoration in the home, respondents with mean score of 3.31 reported that draperies is one of the various ways of utilizing stenciling techniques products for interior decoration in the home. The findings of this study is in line with Alan (2013) who contented curtain, table cloth, wall design and headrest as among the major ways of utilizing stenciling techniques products for interior decoration in the home.

Table 3: Possible benefits associated with the use of stenciling techniques products.

\begin{tabular}{|c|l|c|c|c|c|c|c|c|}
\hline S/N & $\begin{array}{l}\text { What are the possible benefits associated with the use } \\
\text { of stenciling techniques products? }\end{array}$ & $\mathbf{A A}$ & $\mathbf{S D}$ & $\mathbf{D}$ & $\mathbf{X}$ & Sd & Remark \\
\hline 1 & Self employment opportunities & 211 & 45 & 54 & 25 & 3.32 & 0.99 & $\mathrm{Accept}$ \\
\hline 2 & Improvement of available skills & 149 & 92 & 59 & 35 & 3.06 & 1.02 & $\mathrm{Accept}$ \\
\hline 3 & Diverse creativity in design of fabric & 288 & 25 & 5 & 17 & 3.74 & 0.73 & $\mathrm{Accept}$ \\
\hline 4 & Materials for product are cheap and easily sourced & 219 & 44 & 47 & 25 & 3.36 & 0.98 & $\mathrm{Accept}$ \\
\hline 5 & Products are income generating & 230 & 55 & 45 & 5 & 3.52 & 0.78 & $\mathrm{Accept}$ \\
\hline 6 & The crafts are simple & 295 & 5 & 20 & 15 & 3.73 & 0.76 & Accept \\
\hline 7 & The products can be exported & 163 & 74 & 60 & 38 & 3.08 & 1.05 & $\mathrm{Accept}$ \\
\hline
\end{tabular}

Source: Field Survey (2017)

Key

$\begin{array}{lll}\mathrm{X} & = & \text { Mean } \\ \mathrm{Sd} & = & \text { Standard Deviation }\end{array}$

Table 3 above investigated the possible benefits associated with the use of stenciling techniques products. Out of the seven item statement on the possible benefits associated with the use of stenciling techniques products, the seven listed item statement were all accepted by the respondents as the possible benefits associated with the use of stenciling techniques products with mean score range of 3.06 and 3.74. More so, respondents with mean score of 3.32 agreed that self employment opportunities is one of the possible benefits associated with the use of stenciling techniques products, respondents with mean score of 3.06 attested that improvement of available skills is one of the possible benefits associated with the use of stenciling techniques products, respondents with mean score of 3.74 claimed that diverse creativity in design of fabric is one of the possible benefits associated with the use of stenciling techniques products, respondents with mean score 3.36 agreed that materials for product are cheap and easily sourced is one of the possible benefits associated with the use of stenciling techniques products, respondents with mean score of 3.52 reported that products been income generating is one of the possible benefits associated with the use of stenciling techniques products, respondents with mean score of 3.73 claimed 
that the craft is simple, respondents with mean score of 3.08 attested that the products are potential export materials. This finding is in agreement with Ford (2013) who attested that materials for products are cheap and easily sourced.

Table 4: Measurement of the extent the items from stenciling techniques products are suitable for interior decoration

\begin{tabular}{|c|l|c|c|c|c|c|c|l|}
\hline S/N & $\begin{array}{l}\text { To what extent is the items from stenciling } \\
\text { techniques products suitable for interior decoration? }\end{array}$ & & $\mathbf{A}$ & $\mathbf{S D}$ & $\mathbf{D}$ & $\mathbf{X}$ & Sd & Remark \\
\hline 1 & Very high & 102 & 68 & 142 & 23 & 2.74 & 0.96 & Reject \\
\hline 2 & High & 196 & 55 & 65 & 19 & 3.27 & 0.96 & Accept \\
\hline 3 & Moderate & 86 & 118 & 108 & 23 & 2.79 & 0.90 & Reject \\
\hline 4 & Low & 134 & 47 & 140 & 14 & 2.89 & 0.99 & Reject \\
\hline 5 & Very low & 142 & 47 & 126 & 20 & 2.92 & 1.02 & Reject \\
\hline
\end{tabular}

Source: Field Survey (2017)

Key

$\mathrm{X}=$ Mean

$\mathrm{Sd} \quad=\quad$ Standard Deviation

Table 4 above shows the extent to which the items from stenciling techniques products can be suitable for interior decoration. Out of the five like scale on the extent from which stenciling techniques products are suitable for interior decoration, the respondents with mean score of 3.27 were only accepted, while others were rejected. Based on this findings, it is evident that to a high extent, the items from stenciling techniques products are suitable for interior decoration. The outcome of this study is in conformity with Ford (2016) who asserted that to a reasonable extent, stenciling techniques products are suitable for interior decoration.

Table 5: The possible constraints on the use of stenciling techniques products for interior decoration in the home.

\begin{tabular}{|c|l|c|c|c|c|c|c|c|}
\hline S/N & $\begin{array}{l}\text { What are the possible constraints on the use of } \\
\text { stenciling techniques products for interior decoration } \\
\text { in the home }\end{array}$ & $\mathbf{A}$ & $\mathbf{S D}$ & $\mathbf{D}$ & $\mathbf{X}$ & $\mathbf{S d}$ & Remark \\
\hline 1 & $\begin{array}{l}\text { Lack of knowledge about the recent development on the } \\
\text { use of products }\end{array}$ & 170 & 134 & 5 & 26 & 3.34 & 0.85 & Accept \\
\hline 2 & Inadequate finance & 173 & 120 & 24 & 18 & 3.33 & 0.83 & Accept \\
\hline 3 & Inadequate skills & 176 & 130 & 15 & 14 & 3.39 & 0.76 & Accept \\
\hline 4 & Inadequate transportation for movement to isolated areas & 51 & 257 & 10 & 17 & 3.02 & 0.62 & Accept \\
\hline 5 & Inadequate customer patronage & 72 & 233 & 13 & 17 & 3.07 & 0.67 & Accept \\
\hline 6 & Inadequate selling skills & 101 & 179 & 31 & 24 & 3.06 & 0.82 & Accept \\
\hline 7 & Lack of diverse creativity in design of fabric & 181 & 97 & 37 & 20 & 3.31 & 0.89 & Accept \\
\hline
\end{tabular}

Source: Field Survey (2017)

Key

$\mathrm{X}=$ Mean

$\mathrm{Sd}=$ Standard Deviation

From table 5 above, the possible constraints on the use of stenciling techniques products for interior decoration in the home was examined. Out of the seven item statement, all the seven item statement were all accepted by the respondents with mean response range of 3.02 to 3.34 . This was arrived based on the fact that individual item statement on the possible constraints on the use of stenciling techniques products for interior decoration in the home had a mean response score above the criterion mean (2.50). Respondents with mean score of 3.34 agreed that lack of knowledge about the recent development on the use of the products is one of the possible constraints; respondents with mean score of 3.33 attested that inadequate finance is one of the possible constraints; respondents with mean score of 3.39 attested that inadequate skills is one of the possible constraints on the use of stenciling techniques products for interior decoration in the home; respondents with mean score of 3.02 reported that inadequate transportation for movement to isolated areas is one of the major possible constraints; respondents with mean score of 3.07 agreed that inadequate customer patronage is their constraints on the use of stenciling techniques products for interior decoration in the home; respondents with mean score of 3.06 accepted that inadequate selling skills is one of the possible constraints on the use of stenciling techniques products for interior decoration in the home. Finally, respondents with mean score of 3.31 reported that lack of diverse creativity in design of fabric is one of the possible constraints on the use of stenciling techniques products for interior decoration in the home. The findings of this study is in agreement with Anyakoha and Eluwa (2010) who reported that inadequate finance and inadequate skills are the possible constraints on the use of stenciling techniques products for interior decoration in the home. 


\section{Conclusion}

i) The respondents (male and female families in Okigwe Local Government Area of Imo State) attested that the various ways of utilizing stenciling techniques products for interior decoration in the home are pillow case, curtain, table cloth, wall design, headrest, cushion cover, armrest and draperies.

ii) The respondents agreed that the possible benefits associated with the use of stenciling techniques product are; self employment opportunities, improvement of available skills, diverse creativity in design of fabrics, materials for product are cheap and easily sourced, products are income generating, the crafts are simple and the products can be exported.

iii) The respondents asserted that to a high extent, the items from stenciling techniques products are suitable for interior decoration.

iv) The respondents agreed that the possible constraints on the use of stenciling techniques products for interior decoration in the home are; lack of knowledge about the recent development on the use of the products, inadequate finance, inadequate skills, inadequate transportation for movement to isolated areas, inadequate customer patronage, inadequate selling skills and lack of diverse creativity in design of fabric.

v) The respondents attested that there is significant difference in the suitability of the products for household.

\section{Recommendations}

1) Conferences, seminars and workshops should be periodically organized on stenciling techniques for families in Okigwe Local Government Area of Imo State.

2) Government should organize free seminars on stenciling techniques for families in rural areas.

3) Entrepreneurial education on the use of stenciling techniques should be pursued with vigor in all colleges of education and other tertiary institutions where Home Science is offered.

4) Training and re-training programmes should be arranged for all entrepreneurs of stenciling techniques to improve on their skills.

5) There is need to create and promote awareness of the resourcefulness of the stenciling techniques products in interior decoration.

6) The products of the local crafts should be popularized so that they could enjoy wide patronage from many Nigerians.

7) The quality of skill in stenciling printing techniques should be incorporated into the poverty alleviation programme (PAP) of the Federal Government in order to harness their potentials in offering job opportunity and income generation.

\section{REFERENCES}

Alan (2013). The principle of home Decoration. Lippinoh Company Limited, Philadelphia.

Anyakoha, E.U. and Eluwa, M.A. (2010). Home management for schools and colleges. Africa Lenfeb publishers Ltd, Onitsha, Nigeria.

Cullen, T. (1999). History of interior decoration. Eloyk press inc. Toronto, Canada.

Ford, C.F. (2013). Local Crafts and Arts. MacMillian Publishers, Lagos.

Ford, O.U. (2016). The palms. Retrieved April 2010 from the tree of life web project website.

Ford.O.U ( 2013). Dye preparation. Africana publishers Ltd, Ibadan.

Jessy, J. (2013). The art of the 100m, weaving, spinning and dyeing across the world. Rizzoli publishers, Italy.

Magnani, F. and Rivista, R. (2000). Room for the seventies, Fantasia Neil Publisher, London.

Morris, A.P. (2000). Three keys for furniture selection. Vintage press, New York.

Oguntona, S.D. (2014). Batik, the traditional fabric of Indonesia Retrieved on 12/7/2011. 